\title{
Consideration of illegal actions when imposing punishment for environmental crime
}

\author{
Alena Sokolova ${ }^{1}$, Anton Grunin ${ }^{2, *}$, Viktor Lukanin ${ }^{2}$, and Valentin Shemarov ${ }^{2}$ \\ ${ }^{1}$ Vladimir Law Institute of the Federal Penitentiary Service of Russia, Bolshaya Nizhegorodskaya str., \\ 67, 600020, Vladimir, Russia \\ ${ }^{2}$ Academy of the Federal penitentiary service of Russian Federation, 1, Sennaya str., Ryazan, 390000, \\ Russia
}

\begin{abstract}
Both environmental risks and domestic violence exist in all countries of the world. This phenomenon is influenced by various factors: standard of living, ecological situation, environment, traditions, race, nationality and cultural values. This must be taken into account when imposing an appropriate punishment for commission of any illegal act. At the same time, family and domestic violence is not just a negative attribute of life of individual families, but also indicates serious issues of society, in the narrow sense, and the environment, in the broad sense. In connection with restrictions related to Covid-19 introduced in many countries, the level of domestic violence has increased, which proves a direct dependence on external negative factors in the field of health care, ecology, psychology, etc. Analysis of various factors influencing domestic violence has shown that this phenomenon has a high level of latency, and, as a rule, people learn about it only in cases where the consequences of such violence are difficult to hide due to their severity (for example, causing death or serious harm to health against the background of mental deviation). Having reviewed the news feeds over the past five years we can see that the relevance of the topic under consideration is beyond doubt, since the influence of environmental factors on the human psyche is not fully understood, and this aspect, one way or another, leads to the commission of illegal actions, which indicates the importance of balance between the environment, ecology and legality, society. The authors note that there is a synergistic relationship in which humanity interacts with the surrounding world, in all its diversity (water, land, natural resources, flora, fauna, etc.). $\mathrm{n}$ addition, some judgments of the European Court of Human Rights on environmental problems and the environment, protection from domestic violence, including with the participation of Russian Federation as a defendant, were considered. Based on the analysis of the decisions expressed, as well as the norms of national legislation, a theoretical justification for changing the national criminal and environmental legislation, in terms of imposition of punishment, is formulated.
\end{abstract}

${ }^{*}$ Corresponding author: a.copytowa@yandex.ru 


\section{Introduction}

Domestic violence has long become a global issue. Most psychologists argue that this issue is complex, capable of influencing not only the participant in domestic violence, but also being transmitted from generation to generation, affecting the mental state of all family members. The main feature of domestic violence is constancy and frequency. The victim of domestic violence suffers from repetitive situations in when violence (physical, psychological, economic, sexual) comes from a family member. Thus, domestic violence occurs between loved ones, living, as a rule, under the same roof and related marriage and family relations. The most "strong" family member constantly controls another (also a family member or a former family member), tries to control his/her life with the help of fear, strength and power. As a result, the victim of domestic violence lives in an atmosphere of constant fear and experiences psychological and often physical impact. In addition, we can talk about "secondary victimization" of other family members, since people who witness domestic violence experience psychological trauma that accompanies them for the rest of their lives.

To a large extent, this applies to children in front of whom violence was committed by the father in relation to the mother.

\section{Methods}

Various scientific studies were focused on the issue of possibility of taking into account domestic violence when imposing punishment, as well as studying the types of domestic violence. Thus, L.A. Kolpakova in her dissertation study "Violence in the family: the victimological aspect, differentiation of responsibility and issues of legislative technique" notes that Article 63 of the Criminal Code of Russian Federation does not allow to fully take into account domestic violence when sentencing.

V.S. Kharlamov consideres the possibility of state response to criminal domestic violence by taking into account domestic violence as circumstances mitigating punishment. In his scientific work, he continues research in this area made by Honored Scientist of Russian Federation, Doctor of Law, Professor D.A. Shestokov.

Nowadays, there are more and more statements in legal science about the need to take into account domestic violence as a condition for the appointment of criminal legal measures, since the "victim" of domestic violence is not protected by the norms of the current legislation.

When studying the specifics of sentencing for domestic violence, various general scientific and specific scientific methods of cognition were used as conditions for imposing punishment, namely: dialectical and comparative legal methods of scientific knowledge, inductive and deductive methods of formal logic, and others.

\section{Results}

In the course of our research, we concluded that domestic violence is not reflected in the country's criminal legislation.

Currently, due to restrictions associated with Covid-19, there is an increase in domestic violence and an increase in aggressiveness in relationships with loved ones.

Considering the statistics that are freely available, a structural analysis was carried out not only of domestic violence (Figure 1), but also the reaction of the "victim" to domestic violence, which illustrates the high latency of this phenomenon (Figure 2). In addition, it was found that there is no generalized official statistics after 2011, which leads to the lack of a "complete" picture of this phenomenon on a national scale. 


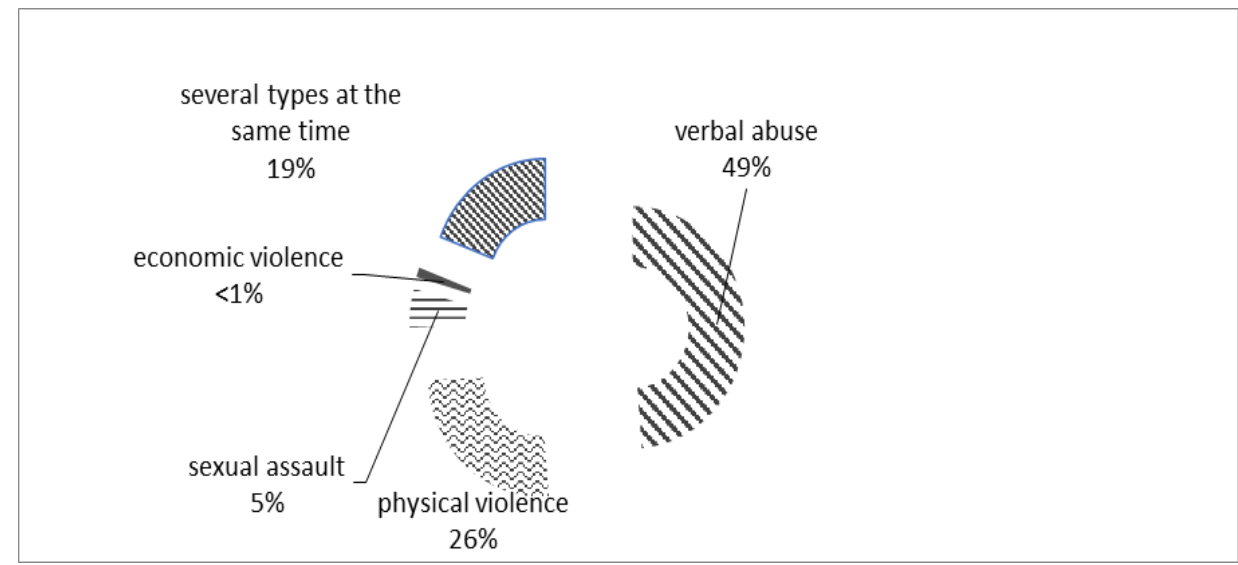

Fig. 1. Structural analysis of types of domestic violence against women aged 15-44 (source: report "Reproductive health of the population of Russia").

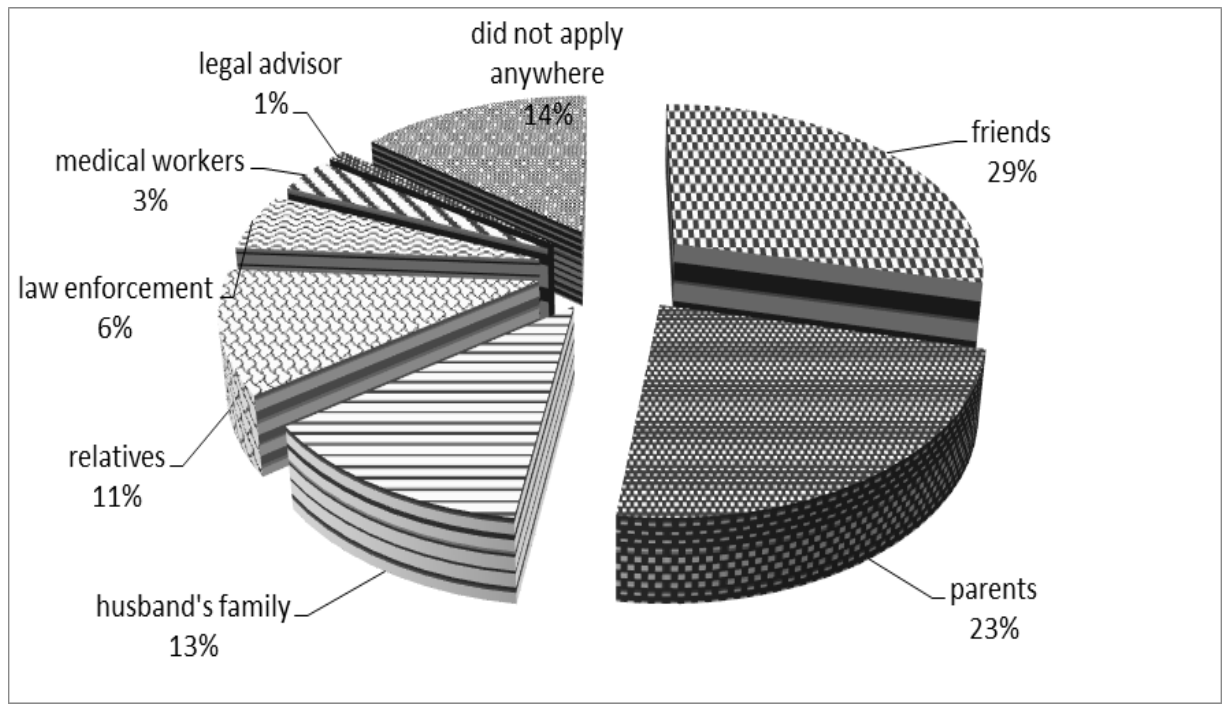

Fig. 2. Analysis of behavior of women aged 15-44 who asked for help by domestic violence (source: report "Reproductive health of the population of Russia").

Negative family and living conditions (systematic bullying, driving to despair by a loved one, etc.) are not reflected in the legislatively enshrined list of circumstances mitigating punishment, in this regard, they are rarely taken into account by authorized law enforcement officers. It is also not possible to take them into account as aggravating circumstances for a similar reason.

After conducting a structural analysis of domestic violence, having studied a sufficient number of resonant criminal cases related to negative family and living conditions, it was concluded that taking into account family and living conditions when imposing a sentence is necessary. We believe that clause " $h$ " part 1 of Art. 61 of the Criminal Code of Russian Federation should be stated in the following wording - "the unlawfulness or immorality of victim's behavior, which was the reason for the crime, as well as the commission of the crime by the guilty person in a grave mental state in connection with cruel, systematic and prolonged abuse of him or a member of his family by the victim ". 
In addition, it is necessary to amend Part 1 of Art. 63 of the Criminal Code of Russian Federation, adding clause "c" to it with the following content: "committing a crime against a member of his family, including a person who was in the past a family member."

It seems that taking into account domestic violence (negative family and living conditions) when appointing measures of criminal law will allow the court to give a fair legal assessment of the behavior of all participants in criminal legal relations, as well as to issue a fair punishment.

\section{Discussion}

There is no special legislation in Russian Federation that guarantees protection of the state for victims of domestic violence. It can be argued that this very shortcoming of national legislation is one of the main reasons for the scale of domestic violence. Analyzing the legislation of foreign countries, we see that the world community does not unequivocally approach the methods of fighting domestic violence. Some states have passed laws against sexual harassment, while others are adopting comprehensive laws on violence against women. So, for example, in the UK there is a law on domestic violence, crimes and victims of crime, in addition, there is a "Family Law". Part 4 of this law is devoted to domestic violence. In the People's Republic of China thwew is a "Law on Fighting Domestic Violence", in 2016 in Germany a law was passed that equates sexual activity with rape, etc. As for Russian Federation, in our country there is not a single legislative act directly related to the fight against domestic violence.

On July 9, 2019, the European Court of Human Rights (hereinafter - the ECHR) recognized the inaction of the authorities of Russian Federation in the fight against domestic violence - the decision of the ECHR case "Volodina V. Russia" (complaint No. 41261/17). V. I. Volodina has been a victim of violence by her former partner since November 2014. The ECHR decision analyzes 9 episodes that happened to the applicant over four years: harassment, humiliation, beatings, forced termination of pregnancy and loss of a child, publication of intimate pictures in the public domain, threats to harm the health and life of the applicant and her child, and how from the impasse, - change of name and emigration from the country. These episodes were considered by the ECHR from the point of view of inaction on the part of law enforcement agencies, since for four years the applicant did not receive any assistance. Thus, for example, no criminal cases were initiated on the facts of beating, as evidenced by numerous written refusals.

According to the findings of the ECHR, the applicant faced systematic physical violence, which was reflected in medical documents and police reports, in addition to bodily injuries V.I.Volodina was subjected to psychological violence, which can be characterized as cruel treatment and falls under the prohibition set out in Article 3 of the Convention for Protection of Human Rights and Fundamental Freedoms (hereinafter - the Convention). on the protection of human rights and fundamental freedoms (hereinafter - the Convention).

The ECHR noted in its decision that the national legislation of Russian Federation does not provide victims of domestic violence with any comparable protection measures. In addition, the court's decision notes the absence of nationwide statistics, which in turn does not give the real extent of the problem of domestic violence. The ECHR awarded citizen V.I. Volodina compensation in the amount of EUR 20,000 and found that Russian Federation had violated Articles 3 and 14 of the Convention.

It should be emphasized that international bodies often deal with issues related to domestiviolence. Thus, the UN Committee on the Elimination of Discrimination against Women (hereinafter referred to as the Committee), on November 6, 2017, considered communication No. 91/2015 in the case of O. G. v. Russian Federation. During the 
examination it was established that the authorities of Russian Federation did not take adequate measures to protect citizen $O$. G. from violence from her former partner. The Committee concluded that the absence of the concept of "domestic violence" in legislative acts had a direct impact on the applicant's ability to demand justice and obtain legal protection and recommended that Russian Federation develop and adopt bills to prevent and suppress violence against women, including domestic violence, as well as "restore criminal prosecution in cases of domestic violence within the meaning of Article 116 of the Criminal Code of Russian Federation".

It should also be noted that the ECHR judgments have repeatedly pointed out the need for active participation of the state in the protection of victims of domestic violence, for example, the ECHR judgment of 16.07.2013 in the case "Mudric v. Republic of Moldova" (complaint No. 74839/10) and the Decision of the ECHR of 28.05.2013 Case "Eremia v. Republic of Moldova" (application no. 3564/11). The ECHR also notes that psychological impact is an important aspect of domestic violence, along with physical and sexual.

Summing up the consideration of international acts, we can conclude that domestic legislation practically does not take into account domestic violence, both as an independent corpus delicti and as a circumstance that affects the appointment of punishment. An exception is the offenses committed against minors who are entrusted with the responsibility for their upbringing (for example, Art. 156 of the Criminal Code of Russian Federation, clause "p" of Part 1 of Art. 63 of the Criminal Code of Russian Federation), where the parents or guardians of the victim can act as perpetrators.

The ineffectiveness of national legislation in the field of domestic violence has been repeatedly noted in international acts, including in the judgments of the ECHR. The world community considers it necessary to introduce clear legal definitions related to domestic violence in national legislation, to introduce court orders prohibiting the aggressor from prosecuting his victim, to take domestic violence into account in the system of conditions for imposing criminal legal measures, as well as other adequate measures.

The scale of domestic violence is confirmed by news feeds and regional statistics. Recently, crimes related to domestic violence are increasingly causing public resonance. So, on March 11, 2017, 39-year-old G.A. Katorova, who lived in the city of Nakhodka, Primorsky Krai, inflicted 11 stabs to her husband. As a result he died. G.A. Katorova, leading a decent and socialized lifestyle, was systematically beaten by her husband for seven years.

On February 15, 2018, the Nakhodka City Court of Primorsky Territory issued a verdict, according to which G.A.Katorova was found guilty of committing a crime under Part 4 of Art. 111 of the Criminal Code of Russian Federation. Despite the fact that the investigation found that her husband was strangling her with a rope from a cross, and there were multiple bruises on her body, she was sentenced to three years of imprisonment without restriction of liberty, with serving the sentence in a correctional colony. At the time of her detention, she had a daughter who, as a result of the incident, lost her father, who had not reached the age of three.

This story caused a huge public outcry, in its support more than one hundred thousand signatures were collected, as a result of the appeal judgment of the Primorsky Regional Court dated 08.22.2018, the verdict of 02.15.2018 was canceled, the plaintiff was acquitted on charges of committing a crime under Part 4, Art. 111 of the Criminal Code of Russian Federation on the grounds provided for in paragraph 2 of Part 1 of Art. 24 of the Code of Criminal Procedure of Russian Federation - for lack of corpus delicti in the actions.

It should be noted that this outcome of the case is rather a rare exception to the rule caused by the professional work of a lawyer than an established judicial practice. This conclusion is confirmed by the case of 28 -year-old Kristina Shidukova, who was found guilty of the murder of her 32-year-old husband (part 1 of article 105 of the Criminal Code 
of Russian Federation). The investigation found that there were systematic domestic conflicts between the spouses, Christina was constantly abused by her husband. This criminal case also caused a huge public outcry - the petition in favor of the woman collected 136 thousand signatures. However, on the basis of the guilty verdict of the jury, the verdict of the Gelendzhik City Court sentenced citizen Shidukova to 8 years in prison in a general regime colony. The appellate instance, having considered the materials of the case, dismissed the complaint.

On July 27, 2018, information appeared in the news feeds, which also caused a public outcry. Maria (17 years old), Angelina (18 years old) and Christina (19 years old) Khachaturian killed their own father Mikhail Khachaturian. The examination established that all family members, namely three sisters, their brother and mother, experienced systematic beatings, threats with weapons, insults and imprisonment in an apartment. In addition, long-term sexual violence was established against one of them.

In November 2019, the public was shocked by the murder of Anastasia Yeshchenko, a graduate student of St. Petersburg University. professor Oleg Sokolov turned out to be the killer. It is a 64-year-old assistant of St. Petersburg State University, a world-renowned historian, author of over 100 scientific works, holder of the French Legion of Honor. He admitted that he killed his beloved, then dismembered her body to get rid of the evidence. As a result of the investigation, it was established that Sokolov totally controlled the life of a young girl, she wanted to leave him, and this was the cause of the tragedy. In addition, the professor has previously received complaints and allegations of ill-treatment and threats.

On December 25, 2020, the St. Petersburg court found O. Sokolov guilty of murder and sentenced him to 12.5 years in a strict regime colony.

Statistics also show the scale of domestic violence. According to the report "Reproductive health of the population of Russia" posted on the official website of the Federal State Statistics Service, more than a third of Russian women $(38 \%)$ suffered verbal violence, one in five $(20 \%)$ experienced physical violence, and $4 \%$ of women became victims of sexual violence from their partners. The following statistics indicate a high latency of domestic violence: $27 \%$ of women who have experienced domestic violence did not seek help because they considered the injuries not serious enough; $24 \%$ of women do not believe in effective help; $16 \%$ were ashamed to ask for help; $8 \%$ did not want to spoil the reputation of their family; $6 \%$ were afraid of divorce, and $5 \%$ were afraid to provoke a new round of violence.

After analyzing the latest figures from Rosstat, human rights activists cite figures for 2018 - 16 million 450 thousand victims of domestic violence in Russian Federation, about $18 \%$ of women suffer from verbal violence, $6 \%$ are victims of physical violence, about $1 \%$ of women have experienced sexual violence. These figures are used by a lawyer specializing in the protection of victims of domestic violence, co-author of the bill on domestic violence A. Popova.

The Chairman of the Federation Council V. I. Matvienko expressed concern about the problem of domestic violence, and also agreed that the lack of official statistics is a huge omission “... Public organizations give only statistics, law enforcement agencies do not have such statistics at all ...". For example, Major General of Police Yu. K. Valyaev, Head of the Main Directorate for the Protection of Public Order and Coordination of Interaction with the Bodies of the Subjects of Russian Federation, in 2019 cited the following figures: $70 \%$ of domestic crimes are committed against women and children; every third murder in Russia is committed in the sphere of family and domestic relations; in every fourth family violent actions of one nature or another are observed.

Generalized statistics are not available from law enforcement agencies, however, regional information, using data interpretation methods, still appears. So, after analyzing open data, it was found that during the press conference, with the Head of the Directorate of 
the Ministry of Internal Affairs of Russia for the Pskov Region, Major General of Police A. V. Ovsyannikov, announced that in the Pskov region from 5 to 7 facts of domestic violence are recorded every day.

As of December 2019, registered after incidents of domestic violence in the Pskov region there are 618 people. In Udmurtia, in 2018, 1,669 crimes were committed on the basis of family and household matters. The Rostov region does not keep statistics of victims of domestic violence, only 216 women were received who applied to the Center for Social Assistance to Families and Children in Rostov-on-Don with complaints about domestic violence. In the Volgograd region in 2018, 5951 crimes against women were recorded, but the exact number of victims of domestic violence has not been established. According to the data published in the statistics of the All-Russian Hotline for Women Victims of Domestic Violence, about $70-90 \%$ of women do not seek help from law enforcement agencies. Thus, modern society (both citizens and state structures) simply does not represent the real scale of domestic violence, which makes the authorities' policy in this area ineffective.

Accordingly, the state should take general measures to protect victims of domestic violence. As noted above, the national legislative framework does not provide for special offenses and other offenses directly related to domestic violence, and such violence is not reflected in the number of circumstances, both aggravating and mitigating punishment.

According to research conducted by the correspondents of Mediazona and Novaya Gazeta, about $80 \%$ of women convicted under Art. 105 of the Criminal Code of Russian Federation were victims of domestic violence, the crime was committed as a result of the use of self-defense. The journalists analyzed the sentences under Part 1 of Art. 108 of the Criminal Code of Russian Federation for the period from 2011 to 2018 from the portal "Judicial and Regulatory Acts of Russian Federation". Following results were obtained: about $83 \%$ of women defended themselves from their husband (cohabitant, sexual partner), who systematically beat the convict; $8 \%$ - from family members and close relatives and only $4 \%$ from a familiar person. In the course of the research it was found that the victim of domestic violence, on average, lives in an atmosphere of violence from one year to 10 years ( $75 \%$ of women), over $7 \%$ of women live in the risk zone for more than 10 years.

However, these family and living conditions are not reflected in the legislatively enshrined list of circumstances mitigating punishment, in this regard, they are rarely subject to accounting by authorized law enforcement officers. To take them into account as aggravating is generally not possible, for a similar reason.

\section{Conclusion}

As a result of the structural analysis of such a phenomenon, as domestic violence, following is established. Taking into account negative family and living conditions when sentencing is a necessary and mandatory requirement to achieve the goals and objectives of criminal legislation.

Taking into account family and domestic violence, when appointing measures of criminal law, will allow the court to give a fair legal assessment of behavior of all participants in criminal legal relations, as well as to issue a fair punishment.

Separately, it should be emphasized that for a qualitative structural analysis of domestic violence, quantitative indicators, it is necessary to form a general statistical database in the country. The lack of generalized official information does not allow the development of an effective state policy in this region.

\section{Acknowledgments}


The authors express their deep gratitude to the management of the Academy of Law and Management of the Federal Penitentiary Service of Russia and the Vladimir Law Institute of the Federal Penitentiary Service of Russia, for help and support provided in the conduct of this study. The authors confirm the absence of a conflict of interest.

\section{References}

1. M. Pisklakova-Parker, A. Sinelnikova, Staying Alive: Violence Against Women in Russia (Moscow, 2020)

2. Great Britain. Laws. Family Law Act 1996, https://www.legislation.gov.uk/ukpga/1996/27/pdfs/ukpga_19960027_en.pdf

3. Review of the practice of interstate bodies for protection of human rights and fundamental freedoms No. 2 (2018) http://www.consultant.ru

4. Decision of the ECHR of July 16, 2013 "Case "Mudric v. Republic of Moldova "(complaint No. 74839/10) http://www.consultant.ru

5. Judgment of the ECHR of 28.05.2013 "Case "Eremia v. Republic of Moldova" (complaint No. 3564/11) http://www.consultant.ru

6. Judgment of the ECHR from 26.03. 2013 Valiuliene v. Lithuania case Lithuania (application no. 33234/07) (Section II) (extract). SPS "Garant" https://www.base.garant.ru/70470714/

7. It is her own fault! How victims of violence are tried in Russia for self-defense. THE INSIDER Investigation Reporting Analyst, https://www.theins.ru/obshestvo/162594

8. I.D. Gorshkova, I.I. Shurygina, Violence against wives in modern Russian families. Statistics of the All-Russian hotline for women victims of domestic violence (MAKS_Press, M., 2003)

9. E.A. Yunusov, S.M. Vorobiev, A.G. Akhverdyan et al, Dilemas contemporáneos: Educación, Política y Valores 7(10), 83 (2019)

10. V.F. Lapshin, S.A. Korneev et al, E3S Web of Conferences 135, 04063 (2019) DOI: 10.1051 / e3sconf / 201913504063

11. A.A. Brovkina, V.E. Vezlomtsev, S.S. Zakharova et al, E3S Web of Conferences 135, 04066 (2019) DOI: 10.1051 / e3sconf / 201913504066 